OPEN ACCESS

Edited by:

Alessandro Passardi, Romagnolo Scientific Institute for the Study and Treatment

of Tumors (IRCCS), Italy

Reviewed by:

Qing Zhang,

Xuzhou Medical University, China

Yelei Guo,

People's Liberation Army General

Hospital, China

${ }^{*}$ Correspondence:

Ming Liu

mingliu721@aliyun.com

Gang Wang

wgang@scu.edu.cn

${ }^{\dagger}$ These authors have contributed equally to this work

Specialty section: This article was submitted to Gastrointestinal Cancers: Hepato

Pancreatic Biliary Cancers, a section of the journal Frontiers in Oncology

Received: 29 November 2021 Accepted: 18 January 2022

Published: 16 February 2022

Citation:

Zheng X, Liu X, Lei Y, Wang G and Liu M (2022) Glypican-3: A Novel and Promising Target for the Treatment of Hepatocellular Carcinoma. Front. Oncol. 12:824208. doi: 10.3389/fonc.2022.824208

\section{Glypican-3: A Novel and Promising Target for the Treatment of Hepatocellular Carcinoma}

\author{
Xiufeng Zheng ${ }^{1+}$, Xun Liu ${ }^{2+}$, Yanna Lei ${ }^{1}$, Gang Wang ${ }^{2 *}$ and Ming Liu ${ }^{1 *}$ \\ ${ }^{1}$ Department of Abdominal Oncology, West China Hospital, Sichuan University, Chengdu, China, ${ }^{2}$ National Engineering \\ Research Center for Biomaterials, Sichuan University, Chengdu, China
}

Glypican-3 (GPC3) is a membrane-associated proteoglycan that is specifically upregulated in hepatocellular carcinoma (HCC) although rarely or not expressed in normal liver tissues, making it a perfect diagnostic and treatment target for HCC. Several GPC3based clinical trials are ongoing and recently several innovative GPC3-targeted therapeutic methods have emerged with exciting results, including GPC3 vaccine, antiGPC3 immunotoxin, combined therapy with immune checkpoint blockades (ICBs), and chimeric antigen receptor (CAR) T or NK cells. Here, we review the value of GPC3 in the diagnosis and prognosis of HCC, together with its signaling pathways, with a specific focus on GPC3-targeted treatments of HCC and some prospects for the future GPC3based therapeutic strategies in HCC.

Keywords: glypican-3 (GPC3), hepatocellular carcinoma (HCC), cancer immunotherapy, immune checkpoint blockade, chimeric antigen receptor

\section{INTRODUCTION}

Liver cancer is the second-most cause of cancer death throughout the world (8.2\% of the total) (1), and hepatocellular carcinoma (HCC) is the most common type of liver cancer. Despite significant advances in both diagnosis and treatment, only $40 \%$ of HCC is diagnosed at an early stage, and the results of treatment are often disappointing. Surgery is still the preferred treatment. However, only $5 \%-10 \%$ of HCC tumors are suitable for resection, and tumor recurrence occurs in a majority (50\%$70 \%$ ) of patients within five years of surgery. Although liver transplantation offers an alternative, the numbers of suitable donor liver sources are extremely limited, while waiting for the donor liver, the tumor may progress, which may lead to the loss of surgical opportunity or worsen the postoperative prognosis (2). Systemic chemotherapy with oxaliplatin-based regimens has been found to increase the overall survival (OS) by 1.47 months (3). Multiple tyrosine kinase inhibitors, sorafenib (4), used as first-line treatments, while lenvatinib (5) and donafenib were found to be superior to sorafenib in extending the OS in Chinese patients with advanced HCC (6).

Immunotherapy has become a powerful strategy for treating cancer. Anti-programmed cell death protein 1 (PD-1) inhibitors of nivolumab (7) and pembrolizumab (8), anti-CTLA-4 inhibitors of tremelimumab (9) and ipilimumab (10), the preliminary results showed promising antitumor activity in HCC. At present, the general trend in tumor treatment is the use of combination therapy, Atezolizumab combined with bevacizumab was found to improve the patient prognosis with an excellent objective response rate (ORR) in advanced HCC (11), and lenvatinib combined with 
pembrolizumab or sintilimab combined with bevacizumab showed similar results $(12,13)$. Nevertheless, despite the progress of current treatments, there are still limited options for effective systemic treatment of HCC. As a result, its five-year survival rate is only a dismal $18 \%$ (14). Thus, the identification of specific molecular markers and targets would assist both early diagnosis and targeted therapy.

Glypian-3 (GPC3) is a heparan sulfate proteoglycan (HSPG). There are six glypican subtypes, namely, GPCs 1-6, with similar structures consisting of a $60-70 \mathrm{kDa}$ protein connected to the cell membrane by a glycosylphosphatidylinositol (GPI) anchor, 14 conserved cysteine residues, and the last 50 residues at the carboxyl end modified by the heparan sulfate (HS) side-chain. GPC3 has been implicated in a variety of processes, including cell growth, differentiation, and migration $(15,16)$. The specific expression of GPC3 in tumor cells has received widespread attention. Here, we discuss the relevance of GPC3 to HCC diagnosis and prognosis, and also address the signaling pathways used by GPC3 to promote HCC development, and focus on the feasibility of targeting GPC3 for treating HCC.

\section{RELEVANCE OF GPC3 TO THE DIAGNOSIS AND PROGNOSIS OF HCC}

The potential of GPC3 in HCC diagnosis and prognosis is gradually being recognized. Figure 1 compares GPC3 expression in various cancers and normal tissues (17). In1997, Hsu et al. demonstrated that MXR7 (later shown to be GPC3) was more strongly expressed in HCC than AFP (18), but was not visible in either normal liver or benign liver lesions (such as cirrhotic or dysplastic nodules) (19). Immunostaining also demonstrated the presence of GPC3 in small liver tumors (16). Currently, GPC3-targeted imaging includes positron emission tomography (PET) $(20,21)$, magnetic resonance imaging (MRI) (22), and near-infrared imaging (NIR) (23) for the early diagnosis of HCC, showing excellent results and high specificity in HCC. GPC3 is also found in the serum of many HCC patients but not in sera from healthy individuals or patients with hepatitis. Despite the presence of GPC3 being indicative of an HCC diagnosis, a single marker cannot meet the specificity and sensitivity requirements of clinical practice. GPC3 + HSP70 (heat shock protein 70) + GS (glutamine synthetase) is an optimal combination to distinguish early and grade 1 HCC from dysplastic nodules in cirrhosis, strengthening the diagnosis of suspected HCC, especially in a biopsy with few samples $(24,25)$. Other investigations have also proposed some combinations of potential markers, such as arginase-1/heppar-1/ GPC3 (26), GP73/GPC3/CD34 (27), and GPC3/CD34 (28). Elevated levels of GPC3 in tumor cells is related to poor prognosis, as Figure 2 shows (17). For example, the five-year survival of patients positive for GPC3 was considerably reduced compared to that of GPC-3-negative patients (54.5 vs $87.7 \%, \mathrm{P}=$ 0.031 ), with this association between GPC3 level and HCC prognosis demonstrated in many studies (29). The early identification of GPC3-positivity may also predict tumor recurrence after resection, and GPC3 is recognized as an independent prognostic factor for disease-free survival (DFS) (30). A raised serum level of the GPC3 N-terminal subunit

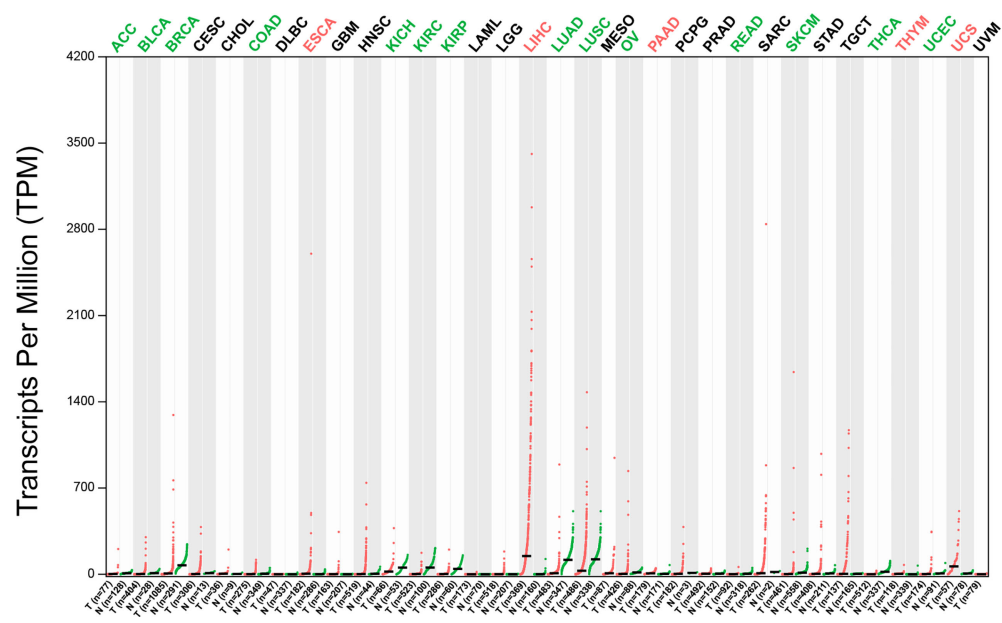

FIGURE 1 | The expression profile of GPC3 across tumor samples and paired normal tissues (Dot plot). Each dot represents expression of samples. T, tumor samples; N, normal tissues; ACC, adrenocortical carcinoma; BLCA, bladder urothelial carcinoma; BRCA, breast invasive carcinoma; CESC, cervical squamous cell carcinoma \& endocervical adeno; CHOL, cholangiocarcinoma; COAD, colon adenocarcinoma; DLBC, lymphoid neoplasm diffuse large B-cell lymphoma; ESCA, esophageal carcinoma, glioblastoma multiforme; HNSC, head \& neck squamous cell carcinoma; KICH, kidney chromophobe cell carcinoma; KIRC, kidney renal clear cell carcinoma; KIRP, kidney renal papillary cell carcinoma; LAML, acute myeloid leukemia; LGG, brain lower grade glioma; LIHC, liver hepatocellular carcinoma; LUCD, lung adenocarcinoma; LUSC, lung squamous cell carcinoma; MESO, mesothelioma; OV, ovarian serous cystadenocarcinoma; PAAD, pancreatic adenocarcinoma; PCPG, pheochromocytoma \& paraganglioma; PRAD, prostate adenocarcinoma; READ, rectum adenocarcinoma; SARC, sarcoma; SKCM, skin cutaneous melanoma; STAD, stomach adenocarcinoma; TGCT, testicular germ cell tumors; THCA, thyroid carcinoma; THYM, thymoma; UCEC, uterine corpus endometrial carcinoma; UCS, uterine carcinosarcoma; UVM, uveal melanoma. 


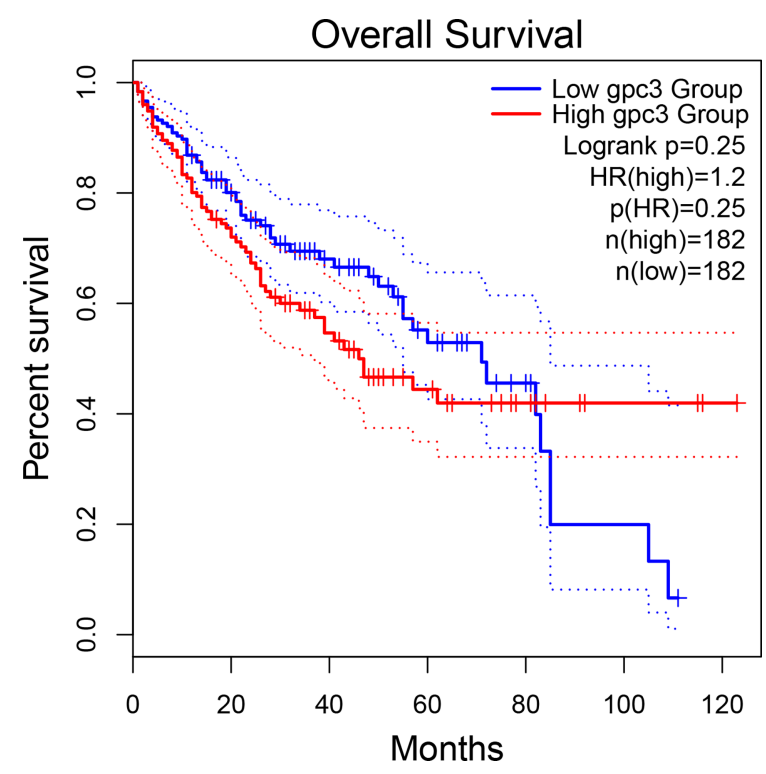

FIGURE 2 | The association between GPC3 expression and HCC prognosis.

antigen (sGPC3N) has also been shown to be independently related to both OS $(\mathrm{p}<0.05)$ and DFS $(\mathrm{p}<0.01)(31)$. Furthermore, both GPC3 and osteopontin (OPN) overexpression are linked to reduced DFS in $\mathrm{HBV}$-positive small HCC, with elevated levels of both molecules indicative of adverse outcomes after curative resection (32). For HCV-positive patients after surgical resection, GPC3 is a prognostic indicator for reduced DFS (33). Consistently, raised levels of GPC3 mRNA have been linked to the development of HCC after liver transplantation (34). Furthermore, a viable GPC3-based immunomagnetic fluorescent system (C6/MMSN-GPC3) has been developed to identify circulating tumor cells (CTCs) in HCC patients' blood, further contributing to the early diagnosis and determination of prognosis (35).

\section{GPC3-ASSOCIATED SIGNALING PATHWAYS IN HCC}

\subsection{Wnt Signaling Pathway}

Wnt signaling plays a major part in HCC pathology and is implicated in cell survival, proliferation, migration, and invasion. The first step in the pathway is the binding of Wnt to the membrane receptor Frizzled (FZD). Wnt signaling involves both canonical and non-canonical pathways, with the former involving the $\beta$-catenin protein $(36,37)$. $\beta$-catenin influences the expression of numerous genes, some of which are associated with cell proliferation and survival (38). GPC3 activates the canonical pathway, thereby stimulating HCC progression $(39,40)$. The human monoclonal anti-GPC3 antibody, HS20, binds the GPC3 HS moiety and has been shown to block the interaction between GPC3 and Wnt3a (41).
GPC3 also interacts with FZD through the HS chain, suggesting that GPC3 may form a signaling complex with both FZD and Wnt (42). The N-leaf cysteine-rich domain (CRD) of GPC3 has a Wnt-binding groove, and the mutation of the notch reduces binding, thereby reducing Wnt activation, and inhibiting the growth of mouse liver cancer (43).

\subsection{Other Signaling Pathways}

The Hippo signaling pathway is responsible for reducing cell contacts and limiting both organ size and tumorigenesis (44). The Hippo pathway is frequently activated in HCC, with activation of the Yes-associated protein (YAP) $(45,46)$. GPC3 knockout inhibits YAP expression at both the mRNA and protein levels and induces the apoptosis of Huh7 cells $(47,48)$. In addition, the abnormal persistence of hedgehog signaling has been directly related to HCC (49-51), and GPC3 appears to be a negative regulator of hedgehog signaling (52-54). Transcription factors zinc-fingers and homeoboxes 2 (ZHX2) (55) and C-myc (56) are involved in the oncogenic activation of GPC3 in HCC to modulate HCC cell growth, proliferation, and differentiation. Sulfatase 2 may up-regulate GPC3 expression, promote fibroblast growth factor (FGF) signal transduction, and reduce the survival rate of HCC patients. A human monoclonal antibody against the GPC3 HS chain inhibited HGF/c-Met pathway-mediated migration and motility in hepatoma cells (41, 57-59). Furthermore, GPC3 could promote the progression and metastatic spread of HCC by influencing the functioning of tumor-associated macrophages (TAM) through macrophage recruitment (60). In Figure 3, we summarize the signal pathways related to GPC3.

\section{GPC3 TARGETED THERAPY FOR HCC}

Since GPC3 is overexpressed in HCC, as Figure 4 shows, various inhibitors targeting GPC3 are under investigation.

\subsection{GPC3-Targeted Antibodies 4.1.1 Monoclonal Antibodies}

GC33 is a recombinant, humanized, high-affinity monoclonal antibody against the GPC3 C-terminus. In preclinical assessments, GC33 was found to promote antibody-dependent cellular cytotoxicity (ADCC) in an antigen-dependent manner (61). The antibody also reduced tumor growth in xenograft models, with the growth reduction correlated approximately to the cell surface antigen level (61). In clinical application, Zhu, et al. enrolled 20 patients in a dose-escalation study, showing no dose-limiting toxicities (DLT) as the maximum tolerated dose fell beyond even the highest dose planned. This suggested the potential clinical efficacy and benefit of GC33 and warrants further evaluation. The minimum serum concentrations of the antibody were above the target concentrations at doses above 5 $\mathrm{mg} / \mathrm{kg}$ and there was a significant reduction in the median time to progression (TTP) between the high-GPC3 group and the low-GPC3 group (26.0 weeks vs 7.1 weeks; $\mathrm{P}=0.033$ ) (62). Ikeda, et al. enrolled seven patients in a similar study in Japan to 


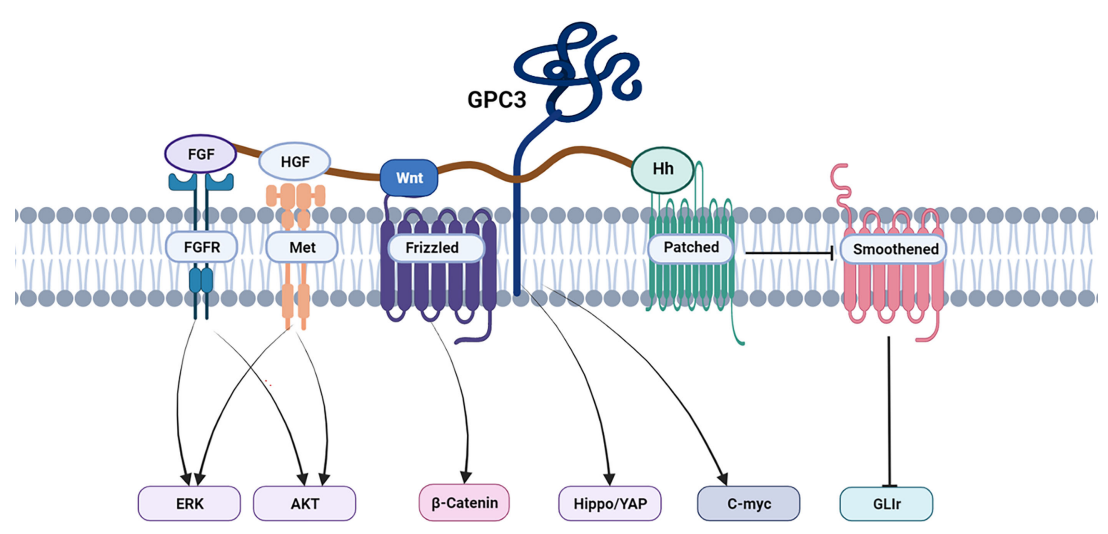

FIGURE 3 | GPC3 associated signaling pathways in HCC.

evaluate the safety and tolerability of GC33. They observed that GC33 was well-tolerated overall, with no DLTs and with the maximum tolerated dose (MTD) not reached. These findings are consistent with those of the First-in-Human although the small sample size did not allow a clear correlation between GPC3 expression and antitumor action (63). Recently, a double-blind, phase II trial of GC33 in 185 patients with chemotherapyunresponsive HCC showed that, although Codrituzumab therapy itself was ineffective, when increasing Codrituzumab exposure, the levels of GPC3 and CD16 in circulating immune cells could predict the efficacy of the drug, suggesting that precision Codrituzumab therapy with this perspective may have potential for treating HCC (64).

Another monoclonal antibody, 32A9, specifically targeting the middle region of GPC3, reduced the growth of HCC tumors in mice. This study then investigated two 32A9-based immunotherapeutic strategies involving an immunotoxin and

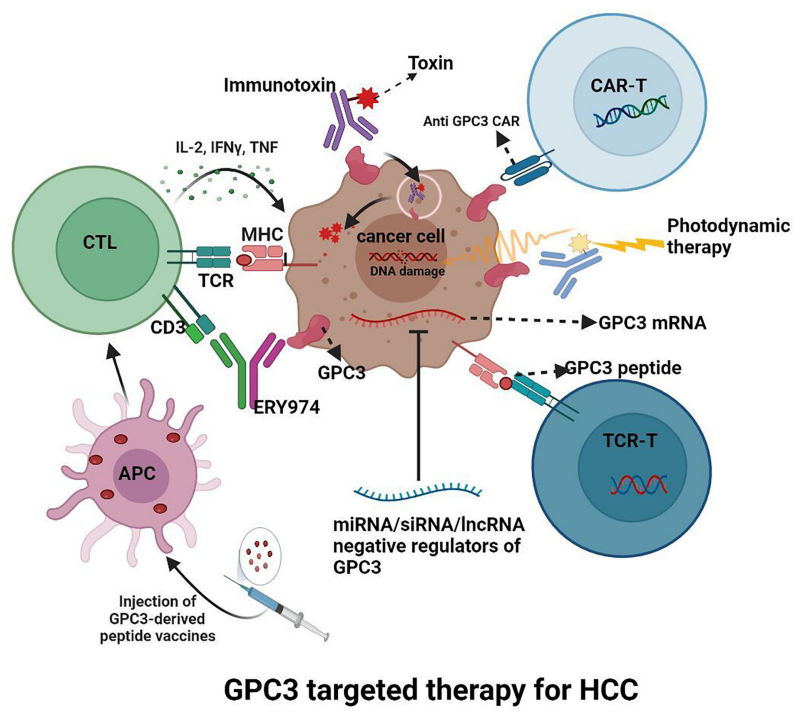

FIGURE 4 | GPC3 targeted therapy for HCC.
CAR-T cells. It was found that the antibody-immunotoxin complex was specifically cytotoxic to GPC3-positive tumor cells, while the 32A9-CAR-T cells destroyed the tumor cells in vitro and promoted regression of HCC xenograft tumors in vivo (65). Feng et al. described an antibody, HN3, that recognized the full GPC3 molecule with high affinity. The antibody promoted cell cycle arrest in G1, inhibiting the growth of GPC3-expressing cells and reducing the growth of xenografts in mice (66). Another human anti-GPC3 monoclonal antibody, HS20, that recognizes the HS moiety on the molecule, was shown to block Wnt signaling and inhibit tumor growth. This antibody also showed no toxicity in mice (41). Thus, although GPC3 is a wellcharacterized HCC-associated antigen, anti-GPC3 therapeutic strategies have had limited clinical success.

\subsubsection{Bispecific Antibodies}

Given the low clinical response rate of monoclonal antibodies targeting GPC3, bispecific antibodies have been investigated. One such bispecific antibody, ERY974, a humanized IgGstructured T cell-redirecting antibody (TRAB) with a common light chain, could bind to both GPC3 and CD3, promoting cytotoxicity through the action of T cell effectors. ERY974 also showed significant non-immunogenic antitumor effects in tumors that were unresponsive to treatment with immune checkpoint (such as PD-1 and CTLA-4) inhibitors. Further investigation showed that ERY974 induced a high degree of inflammation in the tumor microenvironment, with toxicology studies in cynomolgus monkeys showing raised levels of cytokines in the short-term (67). A further report demonstrated a significant improvement in antitumor action in xenograft models using a combination of ERY974 and chemotherapy (68). A phase I clinical trial of this antibody is ongoing (NCT02748837). GPC3/CD47, a bispecific antibody targeting GPC3 and CD47, was effective in preventing tumor growth through recognition of both antigens. This antibody has a long serum half-life with no adverse systemic effects compared to an anti-CD47 antibody alone. The antibody was more effective than treatment with a single anti-CD47 antibody or a combination of individual anti-CD47 and anti-GPC3 antibodies in a mouse xenograft model (69). Taken together, 
these results suggest that anti-GPC3 bispecific antibodies might be potential therapeutic treatments for HCC in the future.

\subsection{GPC3-Derived Peptide/DNA Vaccines}

In addition to antibodies targeting GPC3, the application of GPC3-derived peptide/DNA vaccines is another potentially attractive option for treating HCC. Nakatsura, et al. showed that both HLA-A24(A*2402)-restricted and H-2Kd-restricted GPC3298-306 peptide (EYILSLEEL) peptides, as well as the HLA-A2(A*0201)-restricted GPC3 $144-152$ peptide (FVGEFFTDV), can induce GPC3-reactive cytotoxic T lymphocytes (CTLs) (70, 71). These peptides were subsequently tested as vaccines in preclinical trials using mouse models, and schedules for clinical trials were set up, testing the GPC3298-306 and GPC3144-152 peptides in a Phase I clinical trial. In the trial, one patient showed a partial response (PR), while 4 out of 19 patients with stable disease (SD) showed tumor regression or necrosis beyond the PR criteria. After two months of ongoing treatment, the disease control rate $(\mathrm{PR}+\mathrm{SD})$ was $60.6 \%$ (72). A pilot study (UMINCTR: 000005093) confirmed lymphocyte tumor infiltration by after vaccination with the GPC3 peptides. A Phase II, open-label, single-arm trial (UMIN-CTR: 000002614) enrolled 40 HCC patients who had received either surgery or radiofrequency ablation. In the year following curative treatment, 10 vaccinations were administered, resulting in a significantly lower recurrence rate in patients who had received surgery/radiofrequency ablation with vaccines than in patients who had been treated with surgery only (73). Intravenous administration of GPC3-coupled lymphocytes $\left(\mathrm{LC} / \mathrm{GPC}^{+}\right.$) resulted in the production of both anti-GPC3 antibodies and CTLS, reducing HCC growth and lysing HCC cells in culture (74). Apart from these peptide vaccines, GPC3 DNA vaccines could elicit CTL responses against HCC cell lines, inhibit homogenous tumor growth, and increase the survival rates of xenograft-bearing mice (75). However, despite the potential attraction of a peptide vaccine, the antitumor effects are too weak for treating advanced HCC. Intratumoral peptide injection or combining the peptide vaccine with an anti-PD-1 blocking antibody could feasibly enhance the antitumor effects.

\subsection{Immunotoxins}

GPC3-targeted human nanobody (HN3) immunotoxins have been reported to have potent antitumor effects through the blocking of protein synthesis and downregulation of the Wnt signaling pathway. For example, it was found that intravenously administering the immunotoxin HN3-PE38 either individually or in combination with chemotherapeutic drugs promoted regression of Hep3B and HepG2 tumor xenografts in mice. These results indicate the potential of GPC3 use in immunotoxin-based treatment. However, a drawback was that the side effects and potential toxicity of the immunotoxin, which could thus only be used at low doses $\left(<0.8 \mathrm{mg} \mathrm{kg}^{-}{ }^{1}\right)$ (76). In addition, another team of researchers constructed two mPE24based immunotoxins (HN3-mPE24 and HN3HN3-mPE24). HN3-mPE24 had both high-affinity antigen-binding and strong anti-tumor effects in HCC cells, with minimal side effects in mice even at high doses, and resulted in effective tumor regression and improved survival rates. However, immunogenic effects and the relatively short half-lives of immunotoxins may limit their clinical application (77). To overcome this shortcoming, another research team engineered HN3-ABD-T20 and HN3-ALB1-T20 by adding an albuminbinding domain $(\mathrm{ABD})$ to prolong their half-life. This resulted in effective tumor regression at one-tenth of the dose required for HN3-T20. This increased potency was ascribed to the observed 45-fold prolongation of HN3-ABD-T20's serum retention time. Pharmacokinetic studies in mice showed that HN3-ABD-T20 had a half-life of about 5.5 hours compared to only 7 minutes for HN3-T20. HN3-ABD-T20 thus represents the best option for clinical translation because of its long serum retention, high cytotoxicity, and reduced antigenicity (78). Although further investigations, including clinical trials, are required, these findings suggest that GPC3-targeted immunotoxins have promising potential for treating HCC.

\subsection{GPC3 CAR-T/NK Cells}

In recent years, CAR-T cell therapy has proved effective for treating several cancers, especially hematological malignancies $(79,80)$. To date, there have been several clinical trials exploring the use of GPC3 CAR-T in HCC (Table 1). GPC3-targeted CAR-T cells are able to destroy $\mathrm{GPC}^{+} \mathrm{HCC}$ cells in vitro and $\mathrm{GPC}^{+}{ }^{+} \mathrm{HCC}$ tumor xenografts in mice. Combinations of sorafenib and GPC3-CAR T cells have also proved effective (81). Compared with GPC3-CAR-T cells, the combination of GPC3 and epidermal growth factor receptor (EGFR)-dual-targeting CAR-T cells is more effective in reducing HCC growth (82). To further increase the specificity and decrease the off-target risk, IL-12-armored GPC-3-redirected CAR$\mathrm{T}$ cells were designed which showed greatly improved antitumor effects in mouse models (83). An IL-4/21 inverted cytokine receptor also improved CAR-T cell potency in an immunosuppressive tumor microenvironment (84). GPC3-specific CAR-T cells co-expressing IL-15 and IL-21 (85) or IL-7 and PH-20 (86) were found to be effective against HCC. Interestingly, disruption of PD-1 gene expression in GPC3 CAR-T cells by the CRISPR/Cas9 geneediting system increased the in vivo activity of CAR-T cells against HCC, improving their infiltration levels in mouse models (87). Co-stimulation of DNAX-activating protein 10 was shown to increase the anti-tumor action of CAR-T cells (88). Interestingly, shed GPC3 competed with cell-surface GPC3 CAR-T cell binding, inhibiting the effects of the cells in HCC (89).

There are, however, side effects in the use of CAR-T cells, including tumor lysis syndrome, cytokine release syndrome, and on-target, off-tumor effects. These side-effects, rather than the neoplasm itself, may even be fatal. NK-92 cells have been developed to incorporate improved efficacy with minimal toxicity. The safety and cytotoxic specificity of genetically modified NK-92 cells have been attested to in preclinical trials, suggesting that these cells may be ideal carriers for CAR (90). The anti-tumor efficacy of NK-92/9.28.z cells has been confirmed in many HCC xenografts with different GPC3 levels (91). The combination of CAR-T and GPC3-targeted treatments appear to be highly promising, especially if combined with ICBs. 
TABLE 1 | Clinical trials of GPC3-CAR-T for treating liver cancer.

\begin{tabular}{|c|c|c|c|c|c|}
\hline Interventions & Study Title & Trial No. & status & Phase & Locations \\
\hline \multicolumn{6}{|l|}{ Monotherapy } \\
\hline \multirow[t]{10}{*}{ GPC3 CAR-T cells } & GPC3 CAR-T cells in patients with refractory HCC & NCT03146234 & Completed & $\begin{array}{l}\text { Not } \\
\text { Applicable }\end{array}$ & $\begin{array}{l}\text { Shanghai, } \\
\text { China }\end{array}$ \\
\hline & CAR-T Cells Targeting GPC3 & NCT03884751 & recruiting & 1 & $\begin{array}{l}\text { Zhejiang, } \\
\text { China }\end{array}$ \\
\hline & 4th generation CAR-T cells targeting GPC3 & NCT03980288 & recruiting & 1 & $\begin{array}{l}\text { Zhejiang, } \\
\text { China }\end{array}$ \\
\hline & GPC3 CAR-T Cells for the Hepatocellular Carcinoma & NCT04506983 & $\begin{array}{l}\text { a Not yet } \\
\text { recruiting }\end{array}$ & 1 & $\begin{array}{l}\text { Beijing, } \\
\text { China }\end{array}$ \\
\hline & $\begin{array}{l}\text { A Study of GPC3-targeted T Cells by Intratumor Injection for } \\
\text { Advanced HCC (GPC3-CART) }\end{array}$ & NCT03130712 & Unknown & $1 / 2$ & $\begin{array}{l}\text { Beijing, } \\
\text { China }\end{array}$ \\
\hline & A Study of GPC3 Redirected Autologous T Cells for Advanced HCC & NCT02715362 & Unknown & $1 / 2$ & $\begin{array}{l}\text { Shanghai, } \\
\text { China }\end{array}$ \\
\hline & $\begin{array}{l}\text { GPC3-CAR-T Cells for Immunotherapy of Cancer With GPC3 } \\
\text { Expression }\end{array}$ & NCT03198546 & recruiting & 1 & $\begin{array}{l}\text { Guangdong, } \\
\text { China }\end{array}$ \\
\hline & $\begin{array}{l}\text { A Study of Chimeric Antigen Receptor T Cells Combined With } \\
\text { Interventional Therapy in Advanced Liver Malignancy }\end{array}$ & NCT02959151 & Unknown & $1 / 2$ & $\begin{array}{l}\text { Shanghai, } \\
\text { China }\end{array}$ \\
\hline & CAR-T Cell Immunotherapy for HCC Targeting GPC3 & NCT02723942 & Withdrawn & $1 / 2$ & $\begin{array}{l}\text { Guangdong, } \\
\text { China }\end{array}$ \\
\hline & $\begin{array}{l}\text { GPC3-targeted CAR-T Cell for Treating GPC3 Positive Advanced } \\
\text { HCC }\end{array}$ & NCT04121273 & recruiting & 1 & $\begin{array}{l}\text { Jiangsu, } \\
\text { China }\end{array}$ \\
\hline anti-GPC3 CAR-T & Anti-GPC3 CAR T for Treating Patients With Advanced HCC & NCT02395250 & Completed & 1 & $\begin{array}{l}\text { Shanghai, } \\
\text { China }\end{array}$ \\
\hline \multicolumn{6}{|l|}{ Combined chemotherapy } \\
\hline GAP T cells, Cytoxan, Fludara & $\begin{array}{l}\text { GPC3-specific Chimeric Antigen Receptor Expressed in T Cells for } \\
\text { Patients With Pediatric Solid Tumors (GAP) }\end{array}$ & NCT02932956 & Recruiting & 1 & $\begin{array}{l}\text { Texas, } \\
\text { United } \\
\text { States }\end{array}$ \\
\hline AGAR T cells, Cytoxan, Fludara & $\begin{array}{l}\text { Interleukin-15 Armored GPC3-specific Chimeric Antigen Receptor } \\
\text { Expressed in T Cells for Pediatric Solid Tumors }\end{array}$ & NCT04377932 & $\begin{array}{l}\text { Not yet } \\
\text { recruiting }\end{array}$ & 1 & $\begin{array}{l}\text { Texas, } \\
\text { United } \\
\text { States }\end{array}$ \\
\hline CARE T cells, Cytoxan, Fludara & $\begin{array}{l}\text { Interleukin-15 and -21 Armored Glypican-3-specific Chimeric } \\
\text { Antigen Receptor Expressed in T Cells for Pediatric Solid Tumors }\end{array}$ & NCT04715191 & $\begin{array}{l}\text { Not yet } \\
\text { recruiting }\end{array}$ & 1 & $\begin{array}{l}\text { Texas, } \\
\text { United } \\
\text { States }\end{array}$ \\
\hline TEGAR T cells, Cytoxan, Fludarabine & $\begin{array}{l}\text { T Cells co- Expressing a Second Generation GPC3-specific } \\
\text { Chimeric Antigen Receptor With Cytokines Interleukin-21 and } 15 \text { as } \\
\text { Immunotherapy for Patients With Liver Cancer (TEGAR) }\end{array}$ & NCT04093648 & Withdrawn & 1 & Unknown \\
\hline GLYCAR T cells, Cytoxan, Fludarabine & $\begin{array}{l}\text { GPC3-specific Chimeric Antigen Receptor Expressing T Cells for } \\
\text { Hepatocellular Carcinoma (GLYCAR) }\end{array}$ & NCT02905188 & Recruiting & 1 & $\begin{array}{l}\text { Texas, } \\
\text { United } \\
\text { States }\end{array}$ \\
\hline $\begin{array}{l}\text { Retroviral vector-transduced autologous } \\
\text { T cells to express anti-GPC } 3 \text { CARs, } \\
\text { Fludarabine, Cyclophosphamide }\end{array}$ & $\begin{array}{l}\text { Anti-GPC3 CAR-T for Treating GPC3-positive Advanced } \\
\text { Hepatocellular Carcinoma (HCC) }\end{array}$ & NCT03084380 & Unknown & $1 / 2$ & $\begin{array}{l}\text { Chongqing, } \\
\text { China }\end{array}$ \\
\hline \multicolumn{6}{|l|}{ Combined with other immunotherapy } \\
\hline $\begin{array}{l}\text { CAR-CD19 T cell, CAR-BCMA T cell, } \\
\text { CAR-GPC3 T cell, (and } 3 \text { more...) }\end{array}$ & $\begin{array}{l}\text { Clinical Study of Redirected Autologous T Cells With a Chimeric } \\
\text { Antigen Receptor in Patients With Malignant Tumors }\end{array}$ & NCT03302403 & $\begin{array}{l}\text { Active, not } \\
\text { recruiting }\end{array}$ & $\begin{array}{l}\text { Not } \\
\text { Applicable }\end{array}$ & $\begin{array}{l}\text { Zhejiang, } \\
\text { China }\end{array}$ \\
\hline
\end{tabular}

(U.S. National Library of Medicine | U.S. National Institutes of Health | U.S. Department of Health \& Human Services)(Updated to 2021).

\subsection{Gene Therapy}

The use of gene therapy targeting GPC3 has also been investigated. For example, sulfatase 2 (SULF2) knockdown decreased HCC cell proliferation and migration as well as xenograft growth (58). MicroRNAs (miRNAs) targeting GPC3 have been described, with low levels of miR-1271 related to GPC3 overexpression in HCC, with the miRNA reducing HCC cell growth in a GPC-3-dependent manner and inducing cell death (92). However, although the siRNA technology is effective for the specific silencing of individual genes, it is difficult to apply to a clinical setting as it requires effective delivery with high specificity and minimal toxicity. A GPC3-targeted siRNA nanovector (NP-siRNA-GPC3 antibody for HCC treatment) showed obvious antitumor efficacy in vitro with minimal toxicity and significantly inhibited orthotopic HCC xenografts (93). It is known that long non-coding RNAs (lncRNAs) play significant roles in cancer, including HCC. Knockdown of the HOXA cluster antisense RNA2 (HOXA-AS2) IncRNA reduced GPC3 expression and blocked HCC cell proliferation by G1 arrest, as well as promoting apoptosis and inhibiting HCC cell migration and invasion in vitro (94).

\subsection{Combination of Anti-GPC3 and ICls}

Combining anti-GPC3 antibodies and immune checkpoint inhibitors (ICIs) may be a promising strategy for GPC3associated cancers. For example, treatment with the GC33 antibody increased the infiltration of PD-L1 positive immune cells (such as macrophages and multinucleated giant cells), and 
mGC33 combined with an anti-mPD-L1 monoclonal antibody was more effective against tumors than the antibody alone in xenograft HCC models (95). A Phase I clinical trial of the antiGPC3 monoclonal antibody Codrituzumab combined with atezozumab showed that the agents were well-tolerated and effective in reducing tumor growth in patients with advanced HCC. Among 18 evaluable patients, 1 case was diagnosed as PR, and 10 were SD (including 1 case of unconfirmed PR), of which 6 cases had SD more than 6 months before progression. No DLT was observed (96). Thus, GPC3-CAR-T in combination with anti-PD-1 has increased antitumor efficacy and may have potential for the treatment of HCC patients $(97,98)$.

\subsection{Other Therapies}

The direction of $\mathrm{T}$ cells to tumors is important in cancer therapy. For example, T cells combined with GPC3-specific antibodies are able to destroy GPC3-expressing HCC xenograft tumors in mice (99). Photodynamic therapy (PDT) is a novel method for treating tumors; this relies on the production of reactive oxygen species that induce tumor cell death. This is linked to both vascular shutdown and enhancement of immune activity, but its applications have been limited by the poor tissue penetration of visible light. The use of the near-infrared (NIR) photosensitizer may solve these limitations (100). For example, UCNPs@mSiO2-Ce6-GPC3 nanoparticles are biocompatible, have low toxicity, and produce good cell imaging and antitumor results (101). A novel multi-functional nanostructure, galactose (GAL)- golden nanorods (GNR)siRNA of GPC3(siGPC3) was found to produce both silencing of the GPC3 gene and photothermal action, and may be useful as a synergistic treatment for cancer (102). A study on a GPC3targeting peptide (named G12)-modified liposome (GSI-Lip) coloaded with sorafenib (SF) and IR780 iodide (IR780) showed promising sensitivity and specificity in detecting HCC together with synergistic effects on chemo-photothermal theranostics (103). Thus, the combination of chemotherapeutic drugs and siRNA may have potential in improving anticancer effects using synergistic interactions. SF-PL/siGPC3 with selected sizes and zeta potentials, delivered by PEI-modified liposomes, was shown to accumulate at the tumor site and to enter HCC cells, resulting in suppression of both GPC3 and the pro-proliferation gene cyclin D1 expression a. Intravenous injection of SF-PL/siGPC3 into HepG2-bearing nude mice both blocked tumor growth and prolonged survival (104). GPC3 is involved in the progression of HCC, including stimulation of Wnt signaling, Hedgehog signaling. MiR-542-3p (105) and miR-485-5p (106) block the Wnt signaling pathway, while GANT61 (107) and bufalin (108) affect the Hedgehog signaling pathway to inhibit HCC.

\subsection{Toxicities for Targeting GPC3}

While exhibiting great efficacy, toxicities for targeting GPC3 must be attention. In GPC3 antibody therapy, GC33 was well tolerated in HCC, the most common adverse events (AEs) were the decrease of lymphocyte count (77\%) and NK cell count (77\%), no grade 4 or 5 AEs were reported (63). When GC33 combined with anti-PD-L1 antibody, grade $\geq 3$ AEs were increased aspartate aminotransferase and decreased lymphocyte count (96). Although the phase I clinical data of ERY974 have not been published, in animal trials, the most prominent AEs is cytokine release syndrome (CRS), an acute inflammatory syndrome resulted from the activation of immune cells and release of pro-inflammatory cytokines, however, cytokine release can be managed by corticosteroid premedication (67). In GPC3 vaccine therapy, there are reports of patients with tumor lysis syndrome after the second GPC3 peptide injection, which led to high fever, liver failure, and death (109). Thus, researchers need to optimize the balance between superior tumor-killing abilities and severe tumor lysis syndrome. In GPC3 CAR-T therapy, the commonest grade 3/4 adverse event was hematotoxicity, mainly due to transient lymphocyte count reduction resulted from lymphatic depletion $(110,111)$. Moreover, cytokine release syndrome (CRS), an acute inflammatory syndrome resulted from the activation of immune cells and release of pro-inflammatory cytokines, should be taken seriously. In a phase I clinical trial of GPC3 CAR-T for HCC, CRS occurred in 9/13 patients, including 1 case of grade 5 CRS (died on day 19) (110). In another study, CRS occurred in all patients, with a 50\% incidence of grade $\geq 3$ CRS (3/ 6) (111). In addition, neurotoxicity is related to CRS, cytokines are elevated not only in blood, but also in cerebrospinal fluid, and its clinical symptoms mainly include headache and disturbance of consciousness (112). Fortunately, administrate high-dose corticosteroids or IL-6 receptor antagonist drug tocilizumab was able to alleviate CRS (113). In patients with high tumor load, there is a more severe CRS (114).The use of CAR-T either in the early stage of disease course or after reducing tumor burden may significantly reduce the risk of severe CRS. Despite the low expression of GPC3 in normal adult tissues (115), "ontarget off-tumor" may lead to disastrous side effects. GPC3 is expressed in placenta and endometrium $(116,117)$, suggesting that female patients, especially pregnant patients, may have a high risk of "on-target off-tumor". Furthermore, a small amount of GPC3 was expressed in normal renal tubular and testicular germ cells (115), so renal function should be monitored during targeted GPC3 treatment, and reproductive protection should also be paid attention to in infertile men. At present, assembling suicide genes, synthetic notch receptors, on-switch CAR, bispecific CAR-T cells can help prevent healthy cells from CAR-T attacking (118). At present, no obvious toxicity has been reported in GPC3 related gene therapy, immunotoxin and photodynamic therapy $(78,93,101)$.

\section{CONCLUSION}

Hepatocellular carcinoma has an extremely poor survival rate. To improve both the outcome and quality of life of these patients, it is necessary to discover and develop new means of treating the disease. GPC3 is specifically associated with liver cancer and, although it is useful in HCC diagnosis, an individual marker is not able to meet the needs of clinical therapeutic application. While using a panel of multiple markers greatly improves the rate of early cancer detection, this only strengthens the suspected diagnosis of HCC, so further 
exploration into increasing the sensitivity and specificity of these markers is required.

GPC3 has exceptional cancer specificity and is currently being investigated as a global target for cancer-targeted therapies and immunotherapies. A series of antibodies against HCC is currently in clinical and preclinical trials. However, single anti-GPC3 antibody therapy does not kill liver cancer altogether, which may need to achieve high target saturation in tumor cells to induce any beneficial effect. Bispecific antibodies recognize different epitopes on the antigen simultaneously, overcoming the shortcomings of traditional monoclonal antibodies and showing excellent results in animal experiments, but these results require verification in clinical trials; nevertheless, the promising results suggest the potential of developing combined immunotherapies by optimizing antibody structures and raising antibodies against multiple targets. Secondgeneration GPC3-based immunotherapies, such as CAR-T and TCR engineering $\mathrm{T}$ cell therapy, have attracted worldwide attention. CAR-T can effectively kill tumor cells with low expression of cell surface antigens, which will expand substantially in the body during treatment of patients. However, CAR-T cells only show moderate anti-tumor activity in patients with solid tumors, including liver cancer, partly because of their specific immune microenvironment, containing the vascular-stromal barrier reduces the expansion, persistence and penetration of CAR-T; immune checkpoints and immunosuppressive cells allow HCC to undergo immune escape (119). The CAR co-expressing IL15 and IL-21 showed improved activity. In addition, the toxicity

\section{REFERENCES}

1. Bray F, Ferlay J, Soerjomataram I, Siegel R, Torre L, Jemal A. Global Cancer Statistics 2018: GLOBOCAN Estimates of Incidence and Mortality Worldwide for 36 Cancers in 185 Countries. CA Cancer J Clin (2018) 68:394-424. doi: 10.3322/caac.21492

2. Forner A, Reig M, Bruix J. Hepatocellular Carcinoma. Lancet (London England) (2018) 391:1301-14. doi: 10.1016/S0140-6736(18)30010-2

3. Qin S, Bai Y, Lim H, Thongprasert S, Chao Y, Fan J, et al. Randomized, Multicenter, Open-Label Study of Oxaliplatin Plus Fluorouracil/Leucovorin Versus Doxorubicin as Palliative Chemotherapy in Patients With Advanced Hepatocellular Carcinoma From Asia. J Clin Oncol (2013) 31:3501-8. doi: 10.1200/JCO.2012.44.5643

4. Llovet JM, Ricci S, Mazzaferro V, Hilgard P, Gane E, Blanc J-F, et al. Sorafenib in Advanced Hepatocellular Carcinoma. N Engl J Med (2008) 359:378-90. doi: 10.1056/NEJMoa0708857

5. Kudo M, Finn RS, Qin S, Han KH, Ikeda K, Piscaglia F, et al. Lenvatinib Versus Sorafenib in First-Line Treatment of Patients With Unresectable Hepatocellular Carcinoma: A Randomised Phase 3 Non-Inferiority Trial. Lancet (London England) (2018) 391:1163-73. doi: 10.1016/S0140-6736(18)30207-1

6. Qin S, Bi F, Gu S, Bai Y, Chen Z, Wang Z, et al. Donafenib Versus Sorafenib in First-Line Treatment of Unresectable or Metastatic Hepatocellular Carcinoma: A Randomized, Open-Label, Parallel-Controlled Phase II-III Trial. J Clin Oncol (2021) 39:JCO2100163. doi: 10.1200/JCO.21.00163

7. El-Khoueiry AB, Sangro B, Yau T, Crocenzi TS, Kudo M, Hsu C, et al. Nivolumab in Patients With Advanced Hepatocellular Carcinoma (CheckMate 040): An Open-Label, Non-Comparative, Phase 1/2 Dose Escalation and Expansion Trial. Lancet (London England) (2017) 389:2492-502. doi: 10.1016/S0140-6736(17)31046-2

8. Zhu AX, Finn RS, Edeline J, Cattan S, Ogasawara S, Palmer D, et al. Pembrolizumab in Patients With Advanced Hepatocellular Carcinoma Previously Treated With Sorafenib (KEYNOTE-224): A Non-Randomised, caused by CAR-T has limited the application. Therefore, optimization of the CAR structure to enhance the in vivo peak expansion and safe half-life of CAR-T warrants further investigation. It is also possible that the surviving cells may cease to express GPC3 during the treatment, resulting in drug resistance. GPC3-negative tumors may also grow and develop drug resistance under such therapeutic pressure. Therefore, the exploration of novel targets and combination therapies are future goals for HCC research.

\section{AUTHOR CONTRIBUTIONS}

$\mathrm{XZ}$ and $\mathrm{XL}$ gathered information and designed the review. YL drew the pictures. ML and GW critically revised the manuscript. All authors contributed to the article and approved the submitted version.

\section{FUNDING}

This work was supported by the National Natural Science Foundation of China (31971390), Sichuan Science and Technology Program (2021YFH0142), and 1.3.5 Project for Disciplines of Excellence, West China Hospital, Sichuan University (Grant No. ZYJC21043).
Open-Label Phase 2 Trial. Lancet Oncol (2018) 19:940-52. doi: 10.1016/S14702045(18)30351-6

9. Sangro B, Gomez-Martin C, de la Mata M, Iñarrairaegui M, Garralda E, Barrera P, et al. A Clinical Trial of CTLA-4 Blockade With Tremelimumab in Patients With Hepatocellular Carcinoma and Chronic Hepatitis C. J Hepatol (2013) 59:81-8. doi: 10.1016/j.jhep.2013.02.022

10. Gordan J, Kennedy E, Abou-Alfa G, Beg M, Brower S, Gade T, et al. Systemic Therapy for Advanced Hepatocellular Carcinoma: ASCO Guideline. J Clin Oncol (2020) 38:4317-45. doi: 10.1200/JCO.20.02672

11. Finn RS, Ducreux M, Qin S, Galle PR, Zhu AX, Ikeda M, et al. IMbrave150: A Randomized Phase III Study of 1L Atezolizumab Plus Bevacizumab vs Sorafenib in Locally Advanced or Metastatic Hepatocellular Carcinoma. J Clin Oncol (2018) 36:TPS4141-TPS4141. doi: 10.1200/JCO.2018. 36.15_suppl.TPS4141

12. Finn RS, Ikeda $M$, Zhu AX, Sung $M W$, Baron $A D$, Kudo $M$, et al Phase Ib Study of Lenvatinib Plus Pembrolizumab in Patients With Unresectable Hepatocellular Carcinoma. J Clin Oncol Off J Am Soc Clin Oncol (2020) 38:2960-70. doi: 10.1200/JCO.20.00808

13. Ren Z, Xu J, Bai Y, Xu A, Cang S, Du C, et al. Sintilimab Plus a Bevacizumab Biosimilar (IBI305) Versus Sorafenib in Unresectable Hepatocellular Carcinoma (ORIENT-32): A Randomised, Open-Label, Phase 2-3 Study. Lancet Oncol (2021) 22:977-90. doi: 10.1016/S1470-2045(21)00252-7

14. Liver Cancer. Statistics.Approved by the Cancer.Net Editorial Board. (2020).

15. Filmus J, Selleck S. Glypicans: Proteoglycans With a Surprise. J Clin Invest (2001) 108:497-501. doi: 10.1172/JCI200113712

16. De Cat B, David G. Developmental Roles of the Glypicans. Semin Cell Dev Biol (2001) 12:117-25. doi: 10.1006/scdb.2000.0240

17. Tang Z, Kang B, Li C, Chen T, Zhang Z. GEPIA2: An Enhanced Web Server for Large-Scale Expression Profiling and Interactive Analysis. Nucleic Acids Res (2019) 47:W556-60. doi: 10.1093/nar/gkz430

18. Hsu H, Cheng W, Lai P. Cloning and Expression of a Developmentally Regulated Transcript MXR7 in Hepatocellular Carcinoma: Biological 
Significance and Temporospatial Distribution. Cancer Res (1997) 57:517984.

19. Capurro M, Wanless I, Sherman M, Deboer G, Shi W, Miyoshi E, et al. Glypican-3: A Novel Serum and Histochemical Marker for Hepatocellular Carcinoma. Gastroenterology (2003) 125:89-97. doi: 10.1016/S0016-5085 (03)00689-9

20. Yang X, Liu H, Sun C, Natarajan A, Hu X, Wang X, et al. Imaging of Hepatocellular Carcinoma Patient-Derived Xenografts Using ${ }^{89} \mathrm{Zr}$-Labeled Anti-Glypican-3 Monoclonal Antibody. Biomaterials (2014) 35:6964-71. doi: 10.1016/j.biomaterials.2014.04.089

21. Sham J, Kievit F, Grierson J, Miyaoka R, Yeh M, Zhang M, et al. Glypican-3Targeted 89Zr PET Imaging of Hepatocellular Carcinoma. J Nucl Med (2014) 55:799-804. doi: 10.2967/jnumed.113.132118

22. Li Y, Chen Z, Li F, Wang J, Zhang Z. Preparation and In Vitro Studies of MRI-Specific Superparamagnetic Iron Oxide Antigpc3 Probe for Hepatocellular Carcinoma. Int J Nanomed (2012) 7:4593-611. doi: 10.2147/IJN.S32196

23. Zhu D, Qin Y, Wang J, Zhang L, Zou S, Zhu X, et al. Novel Glypican-3Binding Peptide for in Vivo Hepatocellular Carcinoma Fluorescent Imaging. Bioconjug Chem (2016) 27:831-9. doi: 10.1021/acs.bioconjchem.6b00030

24. Di Tommaso L, Franchi G, Park Y, Fiamengo B, Destro A, Morenghi E, et al. Diagnostic Value of HSP70, Glypican 3, and Glutamine Synthetase in Hepatocellular Nodules in Cirrhosis. Hepatology (2007) 45:725-34. doi: 10.1002/hep.21531

25. Tremosini S, Forner A, Boix L, Vilana R, Bianchi L, Reig M, et al. Prospective Validation of an Immunohistochemical Panel (Glypican 3, Heat Shock Protein 70 and Glutamine Synthetase) in Liver Biopsies for Diagnosis of Very Early Hepatocellular Carcinoma. Gut (2012) 61:1481-7. doi: 10.1136/ gutjnl-2011-301862

26. Timek D, Shi J, Liu H, Lin F. Arginase-1, HepPar-1, and Glypican-3 are the Most Effective Panel of Markers in Distinguishing Hepatocellular Carcinoma From Metastatic Tumor on Fine-Needle Aspiration Specimens. Am J Clin Pathol (2012) 138:203-10. doi: 10.1309/AJCPK1ZC9WNHCCMU

27. Yao S, Zhang J, Chen H, Sheng Y, Zhang X, Liu Z, et al. Diagnostic Value of Immunohistochemical Staining of GP73, GPC3, DCP, CD34, CD31, and Reticulin Staining in Hepatocellular Carcinoma. J Histochem Cytochem (2013) 61:639-48. doi: 10.1369/0022155413492771

28. Enan E, El-Hawary A, El-Tantawy D, Abu-Hashim M, Helal N. Diagnostic Role of Glypican 3 and CD34 for Differentiating Hepatocellular Carcinoma From Nonmalignant Hepatocellular Lesions. Ann Diagn Pathol (2013) 17:490-3. doi: 10.1016/j.anndiagpath.2013.08.001

29. Shirakawa H, Suzuki H, Shimomura M, Kojima M, Gotohda N, Takahashi S, et al. Glypican-3 Expression is Correlated With Poor Prognosis in Hepatocellular Carcinoma. Cancer Sci (2009) 100:1403-7. doi: 10.1111/ j.1349-7006.2009.01206.x

30. Chen I, Ariizumi S, Nakano M, Yamamoto M. Positive Glypican-3 Expression in Early Hepatocellular Carcinoma Predicts Recurrence After Hepatectomy. J Gastroenterol (2014) 49:117-25. doi: 10.1007/s00535-0130793-2

31. Haruyama Y, Yorita K, Yamaguchi T, Kitajima S, Amano J, Ohtomo T, et al. High Preoperative Levels of Serum Glypican-3 Containing N-Terminal Subunit are Associated With Poor Prognosis in Patients With Hepatocellular Carcinoma After Partial Hepatectomy. Int J Cancer (2015) 137:1643-51. doi: 10.1002/ijc.29518

32. Yu M, Lee Y, Lin S, Wu H, Chen T, Lee W, et al. Recurrence and Poor Prognosis Following Resection of Small Hepatitis B-Related Hepatocellular Carcinoma Lesions are Associated With Aberrant Tumor Expression Profiles of Glypican 3 and Osteopontin. Ann Surg Oncol (2012) 19 (Suppl 3):S455-63. doi: 10.1245/s10434-011-1946-2

33. Yorita K, Takahashi N, Takai H, Kato A, Suzuki M, Ishiguro T, et al. Prognostic Significance of Circumferential Cell Surface Immunoreactivity of Glypican-3 in Hepatocellular Carcinoma. Liver Int (2011) 31:120-31. doi: 10.1111/j.1478-3231.2010.02359.x

34. Wang Y, Zhu Z, Teng D, Yao Z, Gao W, Shen Z. Glypican-3 Expression and its Relationship With Recurrence of HCC After Liver Transplantation. World J Gastroenterol (2012) 18:2408-14. doi: 10.3748/wjg.v18.i19.2408

35. Chu Q, Mu W, Lan C, Liu Y, Gao T, Guan L, et al. High-Specific Isolation and Instant Observation of Circulating Tumour Cell From HCC Patients via
Glypican-3 Immunomagnetic Fluorescent Nanodevice. Int J Nanomed (2021) 16:4161-73. doi: 10.2147/IJN.S307691

36. Pez F, Lopez A, Kim M, Wands J, Caron de Fromentel C, Merle P. Wnt Signaling and Hepatocarcinogenesis: Molecular Targets for the Development of Innovative Anticancer Drugs. J Hepatol (2013) 59:110717. doi: 10.1016/j.jhep.2013.07.001

37. Kolluri A, Ho M. The Role of Glypican-3 in Regulating Wnt, YAP, and Hedgehog in Liver Cancer. Front Oncol (2019) 9:708. doi: 10.3389/ fonc. 2019.00708

38. Clevers H. Wnt/ $\beta$-Catenin Signaling in Development and Disease. Cell (2006) 127:469-80. doi: 10.1016/j.cell.2006.10.018

39. Cumberledge S, Reichsman F. Glycosaminoglycans and WNTs: Just a Spoonful of Sugar Helps the Signal Go Down. Trends Genet (1997) 13:421-3. doi: 10.1016/S0168-9525(97)01275-4

40. Capurro M, Xiang Y, Lobe C, Filmus J. Glypican-3 Promotes the Growth of Hepatocellular Carcinoma by Stimulating Canonical Wnt Signaling. Cancer Res (2005) 65:6245-54. doi: 10.1158/0008-5472.CAN-04-4244

41. Gao W, Kim H, Feng M, Phung Y, Xavier C, Rubin J, et al. Inactivation of Wnt Signaling by a Human Antibody That Recognizes the Heparan Sulfate Chains of Glypican-3 for Liver Cancer Therapy. Hepatology (2014) 60:57687. doi: 10.1002/hep.26996

42. Capurro M, Martin T, Shi W, Filmus J. Glypican-3 Binds to Frizzled and Plays a Direct Role in the Stimulation of Canonical Wnt Signaling. J Cell Sci (2014) 127:1565-75. doi: 10.1242/jcs.140871

43. LiN, Wei L, Liu X, Bai H, Ye Y, Li D, et al. A Frizzled-Like Cysteine-Rich Domain in Glypican-3 Mediates Wnt Binding and Regulates Hepatocellular Carcinoma Tumor Growth in Mice. Hepatology (2019) 70:1231-45. doi: 10.1002/hep.30646

44. Zeng Q, Hong W. The Emerging Role of the Hippo Pathway in Cell Contact Inhibition, Organ Size Control, and Cancer Development in Mammals. Cancer Cell (2008) 13:188-92. doi: 10.1016/j.ccr.2008.02.011

45. Zhou D, Conrad C, Xia F, Park J, Payer B, Yin Y, et al. Mst1 and Mst2 Maintain Hepatocyte Quiescence and Suppress Hepatocellular Carcinoma Development Through Inactivation of the Yap1 Oncogene. Cancer Cell (2009) 16:425-38. doi: 10.1016/j.ccr.2009.09.026

46. Lee K, Lee J, Kim T, Kim T, Park H, Byun J, et al. The Hippo-Salvador Pathway Restrains Hepatic Oval Cell Proliferation, Liver Size, and Liver Tumorigenesis. Proc Natl Acad Sci U S A (2010) 107:8248-53. doi: 10.1073/ pnas.0912203107

47. Li H, Wolfe A, Septer S, Edwards G, Zhong X, Abdulkarim A, et al. Deregulation of Hippo Kinase Signalling in Human Hepatic Malignancies. Liver Int (2012) 32:38-47. doi: 10.1111/j.1478-3231.2011.02646.x

48. Miao H, Pan Z, Lei C, Wen J, Li M, Liu Z, et al. Knockdown of GPC3 Inhibits the Proliferation of Huh7 Hepatocellular Carcinoma Cells Through DownRegulation of YAP. J Cell Biochem (2013) 114:625-31. doi: 10.1002/ jcb. 24404

49. Briscoe J, Thérond P. The Mechanisms of Hedgehog Signalling and its Roles in Development and Disease. Nat Rev Mol Cell Biol (2013) 14:416-29. doi: $10.1038 / \mathrm{nrm} 3598$

50. Salaritabar A, Berindan-Neagoe I, Darvish B, Hadjiakhoondi F, Manayi A, Devi K, et al. Targeting Hedgehog Signaling Pathway: Paving the Road for Cancer Therapy. Pharmacol Res (2019) 141:466-80. doi: 10.1016/ j.phrs.2019.01.014

51. Wang Y, Han C, Lu L, Magliato S, Wu T. Hedgehog Signaling Pathway Regulates Autophagy in Human Hepatocellular Carcinoma Cells. Hepatology (2013) 58:995-1010. doi: 10.1002/hep.26394

52. Capurro M, Li F, Filmus J. Overgrowth of a Mouse Model of SimpsonGolabi-Behmel Syndrome is Partly Mediated by Indian Hedgehog. EMBO Rep. (2009) 10:901-7. doi: 10.1038/embor.2009.98

53. Capurro M, Xu P, Shi W, Li F, Jia A, Filmus J. Glypican-3 Inhibits Hedgehog Signaling During Development by Competing With Patched for Hedgehog Binding. Dev Cell (2008) 14:700-11. doi: 10.1016/j.devcel.2008.03.006

54. Li F, Shi W, Capurro M, Filmus J. Glypican-5 Stimulates Rhabdomyosarcoma Cell Proliferation by Activating Hedgehog Signaling. J Cell Biol (2011) 192:691-704. doi: 10.1083/jcb.201008087

55. Luan F, Liu P, Ma H, Yue X, Liu J, Gao L, et al. Reduced Nucleic ZHX2 Involves in Oncogenic Activation of Glypican 3 in Human Hepatocellular Carcinoma. Int J Biochem Cell Biol (2014) 55:129-35. doi: 10.1016/ j.biocel.2014.08.021 
56. Li L, Jin R, Zhang X, Lv F, Liu L, Liu D, et al. Oncogenic Activation of Glypican-3 by C-Myc in Human Hepatocellular Carcinoma. Hepatology (2012) 56:1380-90. doi: 10.1002/hep.25891

57. Song H, Shi W, Filmus J. OCI-5/Rat Glypican-3 Binds to Fibroblast Growth Factor-2 But Not to Insulin-Like Growth Factor-2. J Biol Chem (1997) 272:7574-7. doi: 10.1074/jbc.272.12.7574

58. Lai J, Sandhu D, Yu C, Han T, Moser C, Jackson K, et al. Sulfatase 2 UpRegulates Glypican 3, Promotes Fibroblast Growth Factor Signaling, and Decreases Survival in Hepatocellular Carcinoma. Hepatology (2008) 47:1211-22. doi: 10.1002/hep.22202

59. Gao W, Kim H, Ho M. Human Monoclonal Antibody Targeting the Heparan Sulfate Chains of Glypican-3 Inhibits HGF-Mediated Migration and Motility of Hepatocellular Carcinoma Cells. PloS One (2015) 10: e0137664. doi: 10.1371/journal.pone.0137664

60. Takai H, Kato A, Kato C, Watanabe T, Matsubara K, Suzuki M, et al. The Expression Profile of Glypican-3 and Its Relation to Macrophage Population in Human Hepatocellular Carcinoma. Liver Int (2009) 29:1056-64. doi: 10.1111/j.1478-3231.2008.01968.x

61. Ishiguro T, Sugimoto M, Kinoshita Y, Miyazaki Y, Nakano K, Tsunoda H, et al. Anti-Glypican 3 Antibody as a Potential Antitumor Agent for Human Liver Cancer. Cancer Res (2008) 68:9832-8. doi: 10.1158/0008-5472.CAN08-1973

62. Zhu A, Gold P, El-Khoueiry A, Abrams T, Morikawa H, Ohishi N, et al. First-In-Man Phase I Study of GC33, a Novel Recombinant Humanized Antibody Against Glypican-3, in Patients With Advanced Hepatocellular Carcinoma. Clin Cancer Res (2013) 19:920-8. doi: 10.1158/1078-0432.CCR12-2616

63. Ikeda M, Ohkawa S, Okusaka T, Mitsunaga S, Kobayashi S, Morizane C, et al. Japanese Phase I Study of GC33, a Humanized Antibody Against Glypican-3 for Advanced Hepatocellular Carcinoma. Cancer Sci (2014) 105:455-62. doi: 10.1111/cas.12368

64. Abou-Alfa G, Puig O, Daniele B, Kudo M, Merle P, Park J, et al. Randomized Phase II Placebo Controlled Study of Codrituzumab in Previously Treated Patients With Advanced Hepatocellular Carcinoma. J Hepatol (2016) 65:289-95. doi: 10.1016/j.jhep.2016.04.004

65. Liu X, Gao F, Jiang L, Jia M, Ao L, Lu M, et al. 32A9, a Novel Human Antibody for Designing an Immunotoxin and CAR-T Cells Against Glypican-3 in Hepatocellular Carcinoma. J Transl Med (2020) 18:295. doi: 10.1186/s12967-020-02462-1

66. Feng M, Gao W, Wang R, Chen W, Man Y-G, Figg WD, et al. Therapeutically Targeting Glypican-3 via a Conformation-Specific SingleDomain Antibody in Hepatocellular Carcinoma. Proc Natl Acad Sci (2013) 110:E1083-91. doi: 10.1073/pnas.1217868110

67. Ishiguro T, Sano Y, Komatsu S, Kamata-Sakurai M, Kaneko A, Kinoshita Y, et al. An Anti-Glypican 3/CD3 Bispecific T Cell-Redirecting Antibody for Treatment of Solid Tumors. Sci Transl Med (2017) 9:eaal4291. doi: 10.1126/ scitranslmed.aal4291

68. Sano Y, Azuma Y, Tsunenari T, Kinoshita Y, Kayukawa Y, Mutoh H, et al. Abstract 3653: Combining ERY974, a Novel T Cell-Redirecting Bispecific Antibody Targeting Glypican-3, With Chemotherapy Profoundly Improved Antitumor Efficacy Over its Monotherapy in Xenograft Model. Cancer Res (2017) 77:3653-3. doi: 10.1158/1538-7445.AM2017-3653

69. Du K, Li Y, Liu J, Chen W, Wei Z, Luo Y, et al. A Bispecific Antibody Targeting GPC3 and CD47 Induced Enhanced Antitumor Efficacy Against Dual Antigen-Expressing HCC. Mol Ther (2021) 29(4): 1572-84. doi: 10.1016/j.ymthe.2021.01.006

70. Nakatsura T, Komori H, Kubo T, Yoshitake Y, Senju S, Katagiri T, et al. Mouse Homologue of a Novel Human Oncofetal Antigen, Glypican-3, Evokes T-Cell-Mediated Tumor Rejection Without Autoimmune Reactions in Mice. Clin Cancer Res (2004) 10:8630-40. doi: 10.1158/10780432.CCR-04-1177

71. Komori H, Nakatsura T, Senju S, Yoshitake Y, Motomura Y, Ikuta Y, et al. Identification of HLA-A2- or HLA-A24-Restricted CTL Epitopes Possibly Useful for Glypican-3-Specific Immunotherapy of Hepatocellular Carcinoma. Clin Cancer Res (2006) 12:2689-97. doi: 10.1158/10780432.CCR-05-2267

72. Sawada Y, Yoshikawa T, Nobuoka D, Shirakawa H, Kuronuma T, Motomura Y, et al. Phase I Trial of a Glypican-3-Derived Peptide Vaccine for Advanced
Hepatocellular Carcinoma: Immunologic Evidence and Potential for Improving Overall Survival. Clin Cancer Res (2012) 18:3686-96. doi: 10.1158/1078-0432.CCR-11-3044

73. Sawada Y, Sakai M, Yoshikawa T, Ofuji K, Nakatsura T. A Glypican-3Derived Peptide Vaccine Against Hepatocellular Carcinoma. Oncoimmunology (2012) 1:1448-50. doi: 10.4161/onci.21351

74. Wu Q, Pi L, Le Trinh T, Zuo C, Xia M, Jiao Y, et al. A Novel Vaccine Targeting Glypican-3 as a Treatment for Hepatocellular Carcinoma. Mol Ther (2017) 25:2299-308. doi: 10.1016/j.ymthe.2017.08.005

75. Li S, Lin J, Qi C, Fu S, Xiao W, Peng B, et al. GPC3 DNA Vaccine Elicits Potent Cellular Antitumor Immunity Against $\mathrm{HCC}$ in Mice. Hepatogastroenterology (2014) 61:278-84. doi: 10.5754/hge121031

76. Gao W, Tang Z, Zhang Y, Feng M, Qian M, Dimitrov D, et al. Immunotoxin Targeting Glypican-3 Regresses Liver Cancer via Dual Inhibition of Wnt Signalling and Protein Synthesis. Nat Commun (2015) 6:6536. doi: 10.1038/ ncomms7536

77. Wang C, Gao W, Feng M, Pastan I, Ho M. Construction of an Immunotoxin, HN3-Mpe24, Targeting Glypican-3 for Liver Cancer Therapy. Oncotarget (2017) 8:32450-60. doi: 10.18632/oncotarget.10592

78. Fleming B, Urban D, Hall M, Longerich T, Greten T, Pastan I, et al. Engineered Anti-GPC3 Immunotoxin, HN3-ABD-T20, Produces Regression in Mouse Liver Cancer Xenografts Through Prolonged Serum Retention. Hepatology (2020) 71:1696-711. doi: 10.1002/hep.30949

79. Porter D, Hwang W, Frey N, Lacey S, Shaw P, Loren A, et al. Chimeric Antigen Receptor T Cells Persist and Induce Sustained Remissions in Relapsed Refractory Chronic Lymphocytic Leukemia. Sci Transl Med (2015) 7:303ra139. doi: 10.1126/scitranslmed.aac5415

80. Finney O, Brakke H, Rawlings-Rhea S, Hicks R, Doolittle D, Lopez M, et al. CD19 CAR T Cell Product and Disease Attributes Predict Leukemia Remission Durability. J Clin Invest (2019) 129:2123-32. doi: 10.1172/ JCI125423

81. Wu X, Luo H, Shi B, Di S, Sun R, Su J, et al. Combined Antitumor Effects of Sorafenib and GPC3-CAR T Cells in Mouse Models of Hepatocellular Carcinoma. Mol Ther (2019) 27:1483-94. doi: 10.1016/j.ymthe.2019.04.020

82. Li K, Qian S, Huang M, Chen M, Peng L, Liu J, et al. Development of GPC3 and EGFR-Dual-Targeting Chimeric Antigen Receptor-T Cells for Adoptive T Cell Therapy. Am J Transl Res (2021) 13:156-67.

83. Liu Y, Di S, Shi B, Zhang H, Wang Y, Wu X, et al. Armored Inducible Expression of IL-12 Enhances Antitumor Activity of Glypican-3-Targeted Chimeric Antigen Receptor-Engineered T Cells in Hepatocellular Carcinoma. J Immunol (2019) 203:198-207. doi: 10.4049/jimmunol.1800033

84. Wang Y, Jiang H, Luo H, Sun Y, Shi B, Sun R, et al. An IL-4/21 Inverted Cytokine Receptor Improving CAR-T Cell Potency in Immunosuppressive Solid-Tumor Microenvironment. Front Immunol (2019) 10:1691. doi: 10.3389/fimmu.2019.01691

85. Batra SA, Rathi P, Guo L, Courtney AN, Fleurence J, Balzeau J, et al. Glypican-3-Specific CAR T Cells Coexpressing IL15 and IL21 Have Superior Expansion and Antitumor Activity Against Hepatocellular Carcinoma. Cancer Immunol Res (2020) 8:309-20. doi: 10.1158/2326-6066.CIR-19-0293

86. Xiong X, Xi J, Liu Q, Wang C, Jiang Z, Yue S, et al. Co-Expression of IL-7 and PH20 Promote Anti-GPC3 CAR-T Tumour Suppressor Activity In Vivo and In Vitro. Liver Int (2021) 41:1033-43. doi: 10.1111/liv.14771

87. Hu W, Zi Z, Jin Y, Li G, Shao K, Cai Q, et al. CRISPR/Cas9-Mediated PD-1 Disruption Enhances Human Mesothelin-Targeted CAR T Cell Effector Functions. Cancer Immunol Immunother CII (2019) 68:365-77. doi: 10.1007/s00262-018-2281-2

88. Zhao R, Cheng L, Jiang Z, Wei X, Li B, Wu Q, et al. DNAX-Activating Protein 10 Co-Stimulation Enhances the Anti-Tumor Efficacy of Chimeric Antigen Receptor T Cells. Oncoimmunology (2019) 8:e1509173. doi: 10.1080/2162402X.2018.1509173

89. Sun L, Gao F, Gao Z, Ao L, Li N, Ma S, et al. Shed Antigen-Induced Blocking Effect on CAR-T Cells Targeting Glypican-3 in Hepatocellular Carcinoma. J Immunother Cancer (2021) 9:e001875. doi: 10.1136/jitc-2020-001875

90. Wang W, Zhou G, Zhang WJI. NK-92 Cell, Another Ideal Carrier for Chimeric Antigen Receptor. Immunotherapy (2017) 9:753-65. doi: 10.2217/ imt-2017-0022

91. Yu M, Luo H, Fan M, Wu X, Shi B, Di S, et al. Development of GPC3Specific Chimeric Antigen Receptor-Engineered Natural Killer Cells for the 
Treatment of Hepatocellular Carcinoma. Mol Ther (2018) 26:366-78. doi: 10.1016/j.ymthe.2017.12.012

92. Maurel M, Jalvy S, Ladeiro Y, Combe C, Vachet L, Sagliocco F, et al. A Functional Screening Identifies Five microRNAs Controlling Glypican-3: Role of miR-1271 Down-Regulation in Hepatocellular Carcinoma. Hepatology (2013) 57:195-204. doi: 10.1002/hep.25994

93. Wang K, Kievit F, Sham J, Jeon M, Stephen Z, Bakthavatsalam A, et al. IronOxide-Based Nanovector for Tumor Targeted siRNA Delivery in an Orthotopic Hepatocellular Carcinoma Xenograft Mouse Model. Small (2016) 12:477-87. doi: 10.1002/smll.201501985

94. Zhang Y, Xu J, Zhang S, An J, Zhang J, Huang J, et al. HOXA-AS2 Promotes Proliferation and Induces Epithelial-Mesenchymal Transition via the miR520c-3p/GPC3 Axis in Hepatocellular Carcinoma. Cell Physiol Biochem (2018) 50:2124-38. doi: 10.1159/000495056

95. Endo M, Kinoshita Y, Adachi K, Narita Y, Amano J, Kato A, et al. Abstract 2747: Anti-Glypican-3 Monoclonal Antibody (Codrituzumab/GC33/ RO5137382) Treatment Enhances Tumor Infiltration of PD-L1-Positive Macrophages, and Combination Therapy With Anti-PD-L1 Monoclonal Antibody Promotes Antitumor Effects. Cancer Res (2018) 78:2747-7. doi: 10.1158/1538-7445.AM2018-2747

96. Cheng A-L, Yen C-J, Okusaka T, Ikeda M, Hsu C-H, Wu S-Y, et al. A Phase I, Open-Label, Multi-Center, Dose-Escalation Study of Codrituzumab, an Anti-Glypican-3 Monoclonal Antibody, in Combination With Atezolizumab in Patients With Locally Advanced or Metastatic Hepatocellular Carcinoma. Ann Oncol (2018) 29:viii234-5. doi: 10.1093/ annonc/mdy 282.080

97. Guo X, Jiang H, Shi B, Zhou M, Zhang H, Shi Z, et al. Disruption of PD-1 Enhanced the Anti-Tumor Activity of Chimeric Antigen Receptor T Cells Against Hepatocellular Carcinoma. Front Pharmacol (2018) 9:1118. doi: 10.3389/fphar.2018.01118

98. Pan Z, Di S, Shi B, Jiang H, Shi Z, Liu Y, et al. Increased Antitumor Activities of Glypican-3-Specific Chimeric Antigen Receptor-Modified T Cells by Coexpression of a Soluble PD1-CH3 Fusion Protein. Cancer Immunol Immunother CII (2018) 67:1621-34. doi: 10.1007/s00262-0182221-1

99. Dargel C, Bassani-Sternberg M, Hasreiter J, Zani F, Bockmann J, Thiele F, et al. T Cells Engineered to Express a T-Cell Receptor Specific for Glypican-3 to Recognize and Kill Hepatoma Cells In Vitro and in Mice. Gastroenterology (2015) 149:1042-52. doi: 10.1053/j.gastro.2015.05.055

100. Baskaran R, Lee J, Yang S. Clinical Development of Photodynamic Agents and Therapeutic Applications. Biomater Res (2018) 22:25. doi: 10.1186/ s40824-018-0140-z

101. Hu J, Shi J, Gao Y, Yang W, Liu P, Liu Q, et al. 808 Nm Near-Infrared LightExcited UCNPs@mSiO-Ce6-GPC3 Nanocomposites For Photodynamic Therapy In Liver Cancer. Int J Nanomed (2019) 14:10009-21. doi: 10.2147/IJN.S221496

102. Liu Y, Tan M, Fang C, Chen X, Liu H, Feng Y, et al. A Novel Multifunctional Gold Nanorod-Mediated and Tumor-Targeted Gene Silencing of GPC-3 Synergizes Photothermal Therapy for Liver Cancer. Nanotechnology (2021) 32:175101. doi: 10.1088/1361-6528/abdbed

103. Mu W, Jiang D, Mu S, Liang S, Liu Y, Zhang N. Promoting Early Diagnosis and Precise Therapy of Hepatocellular Carcinoma by Glypican-3-Targeted Synergistic Chemo-Photothermal Theranostics. ACS Appl Mater Interfaces (2019) 11:23591-604. doi: 10.1021/acsami.9b05526

104. Sun W, Wang Y, Cai M, Lin L, Chen X, Cao Z, et al. Codelivery of Sorafenib and GPC3 siRNA With PEI-Modified Liposomes for Hepatoma Therapy. Biomater Sci (2017) 5:2468-79. doi: 10.1039/C7BM00866J

105. Wu W, Dang S, Feng Q, Liang J, Wang Y, Fan N. MicroRNA-542-3p Inhibits the Growth of Hepatocellular Carcinoma Cells by Targeting FZD7/Wnt Signaling Pathway. Biochem Biophys Res Commun (2017) 482:100-5. doi: 10.1016/j.bbrc.2016.10.136

106. Gao J, Dai C, Yu X, Yin X-B, Zhou F. microRNA-485-5p Inhibits the Progression of Hepatocellular Carcinoma Through Blocking the WBP2/Wnt Signaling Pathway. Cell Signal (2020) 66:109466. doi: 10.1016/j.cellsig. 2019.109466

107. Wang S, Wang Y, Xun X, Zhang C, Xiang X, Cheng Q, et al. Hedgehog Signaling Promotes Sorafenib Resistance in Hepatocellular Carcinoma
Patient-Derived Organoids. J Exp Clin Cancer Res (2020) 39:22. doi: 10.1186/s13046-020-1523-2

108. Sheng X, Sun X, Sun K, Sui H, Qin J, Li Q. Inhibitory Effect of Bufalin Combined With Hedgehog Signaling Pathway Inhibitors on Proliferation and Invasion and Metastasis of Liver Cancer Cells. Int J Oncol (2016) 49:1513-24. doi: 10.3892/ijo.2016.3667

109. Sawada Y, Yoshikawa T, Fujii S, Mitsunaga S, Nobuoka D, Mizuno S, et al. Remarkable Tumor Lysis in a Hepatocellular Carcinoma Patient Immediately Following Glypican-3-Derived Peptide Vaccination: An Autopsy Case. Hum Vaccin Immunother (2013) 9:1228-33. doi: 10.4161/hv.24179

110. Shi D, Shi Y, Kaseb AO, Qi X, Zhang Y, Chi J, et al. Chimeric Antigen Receptor-Glypican-3 T-Cell Therapy for Advanced Hepatocellular Carcinoma: Results of Phase I Trials. Sci Transl Med (2020) 26:3979-89. doi: 10.1158/1078-0432.CCR-19-3259

111. Fang W, Fu Q, Zhao Q, Zheng Y, Liu L, Li Z, et al. Phase I Trial of FourthGeneration Chimeric Antigen Receptor T-Cells Targeting Glypican-3 for Advanced Hepatocellular Carcinoma, Wolters Kluwer Health. J Clin Oncol (2021) 39(15_suppl):4088. doi: 10.1200/JCO.2021.39.15_suppl.4088

112. Lee DW, Santomasso BD, Locke FL, Ghobadi A, Turtle CJ, Brudno JN, et al. ASTCT Consensus Grading for Cytokine Release Syndrome and Neurologic Toxicity Associated With Immune Effector Cells. Biol Blood Marrow Transplant (2019) 25:625-38. doi: 10.1016/j.bbmt.2018.12.758

113. Le RQ, Li L, Yuan W, Shord SS, Nie L, Habtemariam BA, et al. FDA Approval Summary: Tocilizumab for Treatment of Chimeric Antigen Receptor T Cell-Induced Severe or Life-Threatening Cytokine Release Syndrome. Oncologist (2018) 23:943-7. doi: 10.1634/theoncologist.20180028

114. Wei J, Liu Y, Wang C, Zhang Y, Tong C, Dai G, et al. The Model of Cytokine Release Syndrome in CAR T-Cell Treatment for B-Cell Non-Hodgkin Lymphoma. Signal Transduct Target Ther (2020) 5:134. doi: 10.1038/ s41392-020-00256-x

115. Baumhoer D, Tornillo L, Stadlmann S, Roncalli M, Diamantis E, Terracciano L. Glypican 3 Expression in Human Nonneoplastic, Preneoplastic, and Neoplastic Tissues: A Tissue Microarray Analysis of 4,387 Tissue Samples. Am J Clin Pathol (2008) 129:899-906. doi: 10.1309/ HCQWPWD50XHD2DW6

116. Iglesias BV, Centeno G, Pascuccelli H, Ward F, Peters MG, Filmus J, et al. Expression Pattern of Glypican-3 (GPC3) During Human Embryonic and Fetal Development. Histol Histopathol (2008) 23:1333-40. doi: 10.14670/ $\mathrm{HH}-23.1333$

117. Maeda D, Ota S, Takazawa Y, Aburatani H, Nakagawa S, Yano T, et al. Glypican-3 Expression in Clear Cell Adenocarcinoma of the Ovary. Modern Pathol An Off J United States Can Acad Pathol Inc (2009) 22:824-32. doi: 10.1038/modpathol.2009.40

118. Yu S, Yi M, Qin S, Wu K. Next Generation Chimeric Antigen Receptor T Cells: Safety Strategies to Overcome Toxicity. Mol Cancer (2019) 18:125. doi: 10.1186/s12943-019-1057-4

119. Hou AJ, Chen LC, Chen YY. Navigating CAR-T Cells Through the SolidTumour Microenvironment. Nat Rev Drug Discov (2021) 20:531-50. doi: 10.1038/s41573-021-00189-2

Conflict of Interest: The authors declare that the research was conducted in the absence of any commercial or financial relationships that could be construed as a potential conflict of interest.

Publisher's Note: All claims expressed in this article are solely those of the authors and do not necessarily represent those of their affiliated organizations, or those of the publisher, the editors and the reviewers. Any product that may be evaluated in this article, or claim that may be made by its manufacturer, is not guaranteed or endorsed by the publisher.

Copyright ( 2022 Zheng, Liu, Lei, Wang and Liu. This is an open-access article distributed under the terms of the Creative Commons Attribution License (CC BY). The use, distribution or reproduction in other forums is permitted, provided the original author(s) and the copyright owner(s) are credited and that the original publication in this journal is cited, in accordance with accepted academic practice. No use, distribution or reproduction is permitted which does not comply with these terms. 